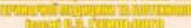

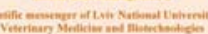

(20)

15

1010 Mine

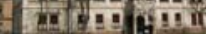

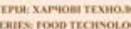

Том 21 Nis 91

2019
Науковий вісник Львівського національного університету ветеринарної медицини та біотехнологій імені С.3. Гжицького. Серія: Харчові технології

Scientific Messenger of Lviv National University of Veterinary Medicine and Biotechnologies.

Series: Food Technologies

ISSN 2519-268X print

https://nvlvet.com.ua/index.php/food

doi: 10.32718/nvlvet-f9119

UDC 637.146:636.292

\title{
Dairy products of treatment and prophylactic action with the new cryopowder
}

\author{
Yu.R. Gachak, O.R. Mikhailitskaya, B.V. Gutyj, L.R. Kuzio, V.I. Beliak \\ Stepan Gzhytskyi National University of Veterinary Medicine and Biotechnologies Lviv, Ukraine
}

Article info

Received 29.01.2019

Received in revised form 04.03 .2019

Accepted 05.03.2019

Stepan Gzhytskyi National University of Veterinary Medicine and Biotechnologies Lviv, Pekarska Str., 50, Lviv, 79010, Ukraine.

Tel.: +38-097-331-99-23

E-mail: hachakyuriy@gmail.com
Gachak, Yu.R., Mikhailitskaya, O.R., Gutyj, B.V., Kuzio, L.R. \& Beliak, V.I. (2019). Dairy products of treatment and prophylactic action with the new cryopowder. Scientific Messenger of Lviv National University of Veterinary Medicine and Biotechnologies. Series: Food Technologies, 21(91), 110-117. doi: 10.32718/nvlvet-f9119

In recent years, more and more attention of scientists is attracted by food products of medical and prophylactic purposes, which contain natural vegetable supplements, which, due to their natural properties, give the dairy products functional properties. The use of natural additives in various aggregate states allows to replenish the deficit of essential nutrients, increase the non-specific resistance of the organism to the action of adverse environmental factors. The clever combination of cryopowders of vegetable origin and dairy basis has great prospects, both technologically and socially. As a milk base, dairy cheese of different fat content was used and the technology of cheese desserts with a different mass fraction of fat using cryopowder "Buriak" was developed. The expediency of use of cryopowder "Buriak" in the technology of new sweet cheesecake masses has been substantiated. The optimum dose of cryopowder "Buriak" is offered. The possibility of using the cryopowder "Buriak" as a component of therapeutic and preventive cheesecake desserts was studied. The amount of this dietary supplement varies depending on the mass fraction of fat in the milk base. Organoleptic, physico-chemical and microbiological characteristics have been studied in the experimental samples of new products. The analysis of organoleptic characteristics of cheese desserts with cryopowder "Buriak" shows that significant changes have not been experienced and fully complied with regulatory requirements. Thus, the color of sweet cheesecakes was light beet, raspberry with separate white splashed chopped powdered cryogenic supplements. The smell of cheesecake remains fresh, sour milk. When adding cryopowder "Buriak" in cheeses, energy value grew. The revealed changes in the amino acid composition of the cheese mass indicate that the use of cryopowder "Buriak" can increase the nutritional and biological value of the protein component. In particular, an increase in the total amount of amino acids has been determined by $1.73 \%$, and in the composition of essential amino acids by $1.16 \%$ and by substitutes - by $2.17 \%$. The offered products expands the domestic assortment of dairy products of functional direction.

Key words: cheese desserts, cryopowder, amino acids, organoleptic parameters, titrated acidity, therapeutic and prophylactic products.

\section{Молочні продукти лікувально-профілактичного спрямування із новим кріопорошком}

\author{
Ю.Р. Гачак, О.Р. Михайлицька, Б.В. Гутий, Л.Р. Кузьо, В.І. Беляк
}

Львівський національний університет ветеринарної медиџини та біотехнологій імені С.3. Гжицького, м. Львів, Украӥна

Останніми роками все більще уваги науковців привертають харчові продукти лікувально-профілактичного спрямування, шчо містять натуральні рослинні біодобавки, які завдяки своїм природним властивостям, надають молочним продуктам функиіональних властивостей. Використання натуральних добавок у різних агрегатних станах дозволяє поповнити дефіиит ессениіальних харчових речовин, підвищити неспецифічну резистентність організму до дії несприятливих факторів зовнішнього середовища. Вміле поєднання кріопорошків рослинного походження та молочної основи несе у собі великі перспективи, як у технологічному, так і сочіальному плані. В якості молочної основи використано кисломолочний сир різної жирності та розроблено технологію сиркових десертів з різною масовою часткою жиру з використанням кріопорошку “Буряк”. Обтрунтовано дочільність викорис- 
тання кріопорошку “Буряк” у технологї нових солодких сиркових мас. Запропоновано оптимальну дозу кріопорошку “Буряк”. Вивчено можливість використання кріопорошку “Буряк” як складника лікувально-профілактичних сиркових десертів. Кількість вказаної кріодобавки змінюється залежно від масової частки жиру молочної основи. У дослідних зразках нової продукиії вивчено органолептичні, фізико-хімічні та мікробіологічні характеристики. Аналіз органолептичних характеристик сиркових десертів із кріопорошком “Буряк” показує, щчо суттєвих змін не зазнали і повністю відповідали нормативним вимогам. Так, колір солодких сиркових мас був світло-буряковий, малиновий з окремими білими вкрапленнями подрібненої порошкоподібної кріогенної біодобавки. Запах сиркових мас залишився свіжим, кисломолочним. При внесенні кріопорошку “Буряк” у сиркові маси енергетична цінність зростала. Виявлені зміни в амінокислотному складі сиркових мас вказують на те, щуо використання кріопорошку “Буряк” дозволяє підвищити харчову та біологічну цінність білкової складової. Зокрема встановлено збільшення загальної кількості амінокислот на 1,73\%, а в складі незамінних амінокислот на 1,16\% та замінних - на 2,17\%. Пропонована продукиія розцирює вітчизняний асортимент молочних продуктів функціонального спрямування.

Ключові слова: сиркові десерти, кріопорошок, амінокислоти, органолептичні показники, титрована кислотність, лікувальнопрофілактичні продукти.

\section{Вступ}

В останні роки проблема із забезпеченням населення раціональними та збалансованими продуктами харчуванням є вкрай актуальною. Враховуючи складні екологічні умови, раціони харчування людей повинні містити в собі численні природні біологічно активні речовини, які здатні підвищувати резистентність організму (Nagovska et al., 2018). Технології нових молочних функціональних продуктів, перш за все, спрямовані на збереження корисних речовин молока та пропонованих біодобавок, не ускладнюючи при цьому традиційний технологічний процес (Mazaraky et al., 2002; Gutyj et al., 2017; Hachak et al., 2018).

Як відомо, кисломолочний сир володіє численними дієтичними та функціональними властивостями (Syrokhman \& Zahorodnia, 2009; Bilyk et al., 2017). Дуже корисний для дітей, вагітних жінок, матерів, які годують дітей материнським молоком, при захворюванні нирок, серця та малокрів'ї. Нежирний сир рекомендується під час ожиріння, хворобах печінки, атеросклерозі, гіпертонії, інфаркті міокарда (Horyuk et al., 2016; Samilyk, 2017). Тому використання кисломолочного сиру у формі сиркових виробів $є$ цікавим та оригінальним рішенням у розширенні сучасного асортименту молочних продуктів функціонального спрямування.

Використання сиркових виробів із фітодобавками буде сприяти одержанню додаткових прибутків внаслідок реалізації нових біологічно-повноцінних і дуже важливих для здоров'я населення продуктів. Буде сприяти вирішенню такої важливої проблеми всіх харчових підприємств, як комплексна переробка сировини i, безпосередньо зв'язаної з нею, проблеми охорони навколишнього середовища (Turchyn et al., 2018). При одержанні комбінованого масла, м'яких, сичужних сирів почали використовувати різновиди плодово-ягідної сировини, диких та лікарських рослин, морські продукти, продукти бджільництва та різноманітні спеції та приправи (Hrek \& Skorchenko, 2012).

Вченими розроблено численні молочно-білкові композиції сиркових паст, напоїв 3 фітодобавками, збагачених вітамінами та мікроелементами (Pavliuk et al., 2013; Pukivskyi et al., 2015; Gutyj et al., 2017).

У сучасних умовах молокопереробні підприємства виготовляють численні молочні продукти, де як солодкі наповнювачі використовують рослинні біодобав- ки. Використовують у вигляді екстрактів, рослинних сиропів чи у натуральному вигляді. Сиропи "Спірулекс", "Спірулекс, збагачений йодом та селеном", “Чорниця форте”, “Шипшина, горобина”, “Шипшина, ехінацея, м’ята”, “Печінковий” та багато-багато інших підсилюють основну функцію молочних продуктів (Hachak, 2011).

Так, доведено доцільність використання пшеничних висівок при виробництві кисломолочних напоїв (Nahovska et al., 2017). Обгрунтовано доцільність використання фітокомпозицій із кропиви дводомної, конюшини, люцерни, черемшини, базиліку, коренів селери та імбиру в якості функціональних складників для збагачення кисломолочних сирів (Hoiko, 2016). Розроблено рецептуру морозива геродієтичного призначення та обгрунтовано вміст основних складників (Bazhai-Zhezherun, 2016). Запропоновано застосовувати різні види та форми біодобавок в технології молочних продуктів лікувально-профілактичних напоїв, особливо фітосиропів та фітоприправ (Boichak et al., 2018).

Розроблено промислову рецептуру соленого сиру “Домашній” із фітоприправами (Ilinska et al., 2017). Також розроблено технологію кисломолочного напою iз симбіотичними властивостями та проведено комплексну технологічну оцінку (Borys \& Tsisaryk, 2016).

Останніми роками на ринок біодобавок активно виходять численні кріодобавки із рослинної сировини. Доведено доцільність використання кріопорошків “Брокколі" та "Морська капуста" в технології солених та солодких сиркових мас різної жирності (Nagovska et al., 2018).

Розроблено солені сиркові маси різної жирності із застосуванням кріопорошків "Морська капуста", “Амарант” та “Броколі”. Дослідні зразки характеризувались нормативними технологічними характеристиками та оригінальною товарознавчою органолептикою (Ilinska et al., 2017).

Рекомендовано використовувати кріопорошки “Гарбуз”, “Амарант”, “Брокколі" та "Морська капуста" в якості біодобавок до “молочної основи” кисломолочного сиру, сиру плавленого, а також сиру “Домашній” (Ilinska et al., 2017).

Запропоновано використання кріопорошків у технології молочних продуктів лікувальнопрофілактичного напрямку (Koberniuk et al., 2018). Розроблено промислові рецептури молочних продуктів функціонального напрямку із кріопорошком морепродуктів (Lisovska \& Puneiko, 2018). I такі дослі- 
дження активно продовжуються та розширюються.

Незважаючи на існуючий асортимент продукції функціонального призначення, поява нових кріопорошків (в тому числі і буряка) та їх використання у технології молочних продуктів дозволить розширити асортимент цієї продукції із оздоровчими властивостями. Враховуючи біосумісність та нетоксичність, виникає можливість тривалого застосування кріопорошків у лікарсько-профілактичних цілях у вигляді добаков до продуктів харчування. Головна цінність таких кріопорошків полягає в тому, що вони $є$ невичерпним джерелом вітамінів, макро- і мікроелементів, флавоноїдів та інших біологічно активних речовин, які не синтезуються організмом людини. Складний комплекс хімічних та біохімічних сполук, які входять до складу кріопорошків, дозволяє віднести їх до продуктів 3 широким спектром лікувальнопрофілактичних та радіопротекторних властивостей, в тому числі і при виробництві сиркових мас, десертів, плавлених сирів та кисломолочних напоїв.

Слід врахувати, що кріопорошки із рослинної сировини можуть бути використані як технологічні добавки, зокрема натуральні поліпшувачі кольору, що дозволить покращити споживчі властивості молочних продуктів. Також насичений аромат кріодобавок дозволить в окремих випадках замінити синтетичні ароматичні речовини.

Враховуючи використання кріопорошків як додаткових рецептурних складників в технології молочних продуктів $є$ цікавим і корисним для науки, з подальшим впровадженням у практику. Такий підхід, у свою чергу, диктує необхідність створення інформаційного поля для науково-технічної творчості в межах розробки сучасних технологій нових сиркових десертів із кріопорошком "Буряк”.

Метою роботи було розробити технологію сиркових десертів нежирних та напівжирних із використанням кріодобавки “Буряк”.

Для досягнення поставленої мети необхідно було розв'язати такі завдання:

- обгрунтувати доцільність використання кріодо- бавки “Буряк” у технології солодких сиркових виробів різної жирності та можливість пї внесення на оптимальній ланці технологічного процесу;

- дослідити органолептичні та фізико-хімічні показники сиркових десертів з різною масовою часткою жиру із використанням кріодобавки "Буряк" при виготовленні та при подальшому їх зберіганні;

- визначити амінокислотний склад білків сиркових десертів різної жирності із використанням кріодобавки "Буряк";

- провести мікробіологічне дослідження готових продуктів із кріодобавкою “Буряк” під час зберігання.

\section{Матеріал і методи досліджень}

Дослідження проводились в умовах ТзОВ “Прометей” (Україна) та наукової лабораторії кафедри технології молока і молочних продуктів Львівського національного університету ветеринарної медицини та біотехнологій ім. С.3. Гжицького (Україна).

Детально вивчали можливість використання кріопорошку “Буряк” у технології нових солодких сиркових десертів з різною масовою часткою жиру. Вивчали технологічні можливості застосування кріопорошку, доцільність попередньої підготовки та пошук необхідних співвідношень при додаванні до молочної основи. Як молочну основу відібрано два види сиру кисломолочного (нежирний та 3 масовою часткою жиру 5\%). Як біодобавку - кріопорошок “Буряк”.

Для досліджень використовували уніфіковану біодобавку - кріопорошок “Буряк”. Рецептуру сирних мас перераховували для промислового виробництва на 1000 кг готового продукту без врахування втрат.

Досліди включали в себе виявлення оптимального співвідношення кріопорошку та молочних основ. Визначальним фактором при застосуванні кріодобавки “Буряк” було збереження нормативних характеристик солодких сиркових мас.

Також було розроблено технологічну схему виробництва нових сиркових мас із кріопорошком "Буряк" (рис. 1).

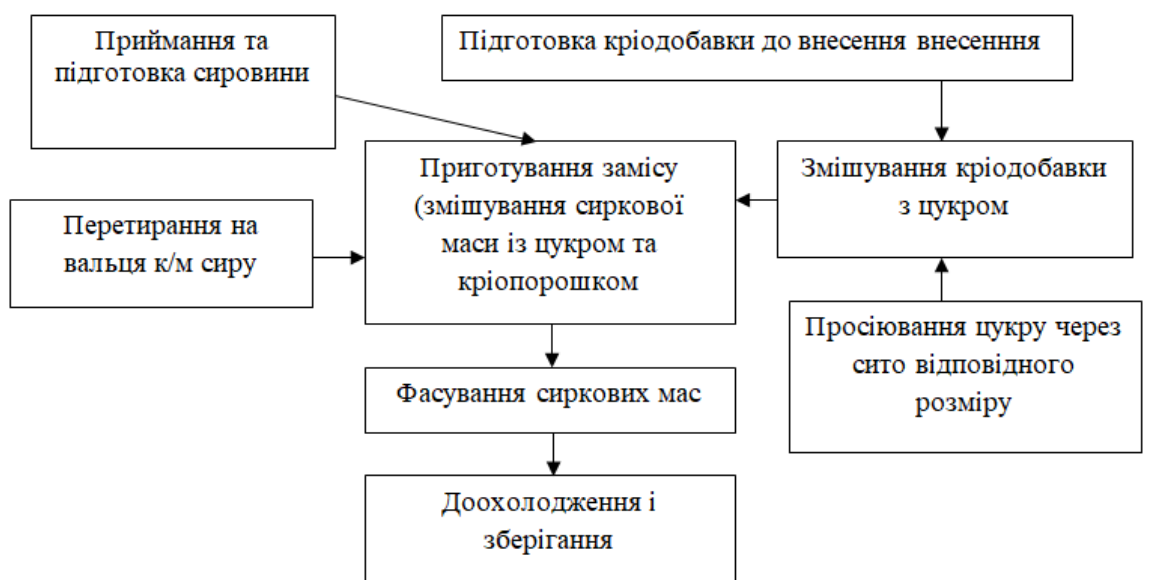

Рис. 1. Технологічна схема виготовлення солодких сиркових мас із кріопорошком “Буряк”

Якісну оцінку досліджуваних сиркових виробів проводили згідно загальноприйнятих методик, нормативних документів. При відборі проб готової продук- ції здійснювали відповідно до ДСТУ ISO 707:2002 "Молоко і молочні продукти. Настанови з відбирання проб” та ДСТУ ISO 5538:2004 "Молоко і молочні 
продукти. Відбирання проб. Контроль за якісними показниками".

\section{Результати та їх обговорення}

За результатами проведених досліджень вибрано найбільш вдалі зразки сиркових десертів із різними кількостями кріопорошку “Буряк”. Саме буряк у стані кріодобавки має широкий спектр застосування в народній медицині, завдяки своїм корисним і цілющим властивостям. Корисні властивості буряка обумовлені наявністю в коренеплодах різних вітамінів, бетаїну, мінеральних речовин, біофлавоноїдів. Вживається як загальнозміцнюючий продукт, що покращує травлення і обмін речовин (Simakhina, 2011).

3 метою проведення дегустаційної оцінки було підібрано по 5 видів рецептур солодких сиркових мас із кріопорошком.

За результатами дегустаційної оцінки (3 5-ти варіантів) було відібрано по одній - найоптимальнішій. Розроблені рецептури сиркових виробів наведені із розрахунку на 1000 кг готового продукту (без врахування виробничих витрат).

У табл. 1 наведено 5 варіантів пропонованих рецептур солодких нежирних сиркових мас із використанням кріопорошку “Буряк” і цукром-пудрою.

За результатами дегустаційної оцінки як оптимальну, вибрано рецептуру № 2 із наступним кількісним складом: сиру кисломолочного нежирного - 917,4 кг; цукру-пудри - 64,3 кг; кріопорошку “Буряк” - 18,3 кг.

У табл. 2 наведено 5 варіантів пропонованих рецептур солодких сиркових десертів із масовою часткою жиру 4,5\% із використанням кріопорошку “Буряк” i цукром-пудрою.

\section{Таблиця 1}

Рецептури солодких нежирних сиркових десертів із додаванням кріопорошку “Буряк”

\begin{tabular}{|c|c|c|c|c|c|c|}
\hline \multirow{2}{*}{ № п/п } & \multirow{2}{*}{ Компоненти } & \multicolumn{5}{|c|}{ Види рецептур } \\
\hline & & 1 & $2 *$ & 3 & 4 & 5 \\
\hline 1 & Сир кисломолочний нежирний & 927,0 & 917,4 & 926,0 & 931,0 & 921,5 \\
\hline 2 & Цукор-пудра & 55,0 & 64,3 & 55,7 & 50,7 & 60,0 \\
\hline 3 & Кріопорошок “Буряк” & 18,0 & 18,3 & 18,3 & 18,3 & 18,5 \\
\hline 4 & Всього & 1000 & 1000 & 1000 & 1000 & 1000 \\
\hline
\end{tabular}

Примітка: $2 *$ - дана рещептура визнана оптимальною по забезпеченню нормативних органолептичних показників

\section{Таблиця 2}

Рецептури солодких напівжирних сиркових десертів із додаванням кріопорошку “Буряк”

\begin{tabular}{|c|c|c|c|c|c|c|}
\hline \multirow{2}{*}{ № П/п } & \multirow{2}{*}{ Компоненти } & \multicolumn{5}{|c|}{ Види рецептур } \\
\hline & & 1 & 2 & $3 *$ & 4 & 5 \\
\hline 1 & Сир кисломолочний 3 м.ч.ж. 5\% & 915,0 & 907,9 & 900,1 & 892,5 & 896,0 \\
\hline 2 & Цукор-пудра & 65,0 & 70,1 & 72,6 & 80,0 & 90,0 \\
\hline 3 & Кріопорошок «Буряк» & 20,0 & 22,0 & 27,3 & 27,5 & 24,0 \\
\hline 4 & Всього & 1000 & 1000 & 1000 & 1000 & 1000 \\
\hline
\end{tabular}

Примітка: $3^{*}$ - дана рецептура визнана оптимальною по забезпеченню нормативних органолептичних показників

За результатами дегустаційної оцінки як оптимальну вибрано рецептуру № 3 із наступним кількісним складом: сиру кисломолочного 3 масовою часткою жиру 5\% - 900,1 кг; цукру-пудри - 72,6 кг; кріопорошку "Буряк" - 27,3 кг.

В комплексі загальної оцінки молочної продукції, оцінки ії потенційним споживачем надзвичайно важливу роль відіграють органолептичні та товарознавчі властивості харчових продуктів, в тому числі і молочних (Nagovska et al., 2018).

Традиційно, властивості продуктів харчування визначають ступенем їх дії на споживача. Зовнішній вигляд сиру, його консистенція і більш чи менш виражений і сильний аромат збуджують зорові і нюхові рецептори людини, діють на його смакосприйняття i викликають ті чи інші реакції, що зумовлюють бажання чи небажання вживати його в їжу.

Органолептичні показники солодких сиркових виробів із використанням кріопорошку наведені у наступній табл. 3.
Аналіз органолептичних характеристик сиркових десертів із кріопорошком “Буряк” показує, що вони суттєвих змін не зазнали і в основному повністю відповідали нормативним вимогам. Так, колір солодких сиркових мас був світло-буряковий та малиновий 3 окремими вкрапленнями подрібненої порошкоподібної кріогенної біодобавки. Запах сиркових мас залишився чистим, кисломолочним. Однак у дослідних зразках відчувався чітко виражений запах доданої кріодобавки.

Смак дослідних зразків був солодким з присмаком кріопорошку, вираженішим у більш солодких зразках. Консистенція дослідних зразків була однорідною, ніжною.

Ще однією важливою групою показників для характеристики сиркових виробів $€$ фізико-хімічні їх характеристики (табл. 4). На відміну від органолептичних показників, фізико-хімічні показники специфічні і характерні для товарів однорідних груп. 
Таблиця 3

Органолептичні показники солодких сиркових виробів із кріопорошком “Буряк”

\begin{tabular}{|c|c|c|c|c|}
\hline № п/п & Назва сиркової маси & Колір, зовнішній вигляд & Запах і смак & Консистенція \\
\hline 1 & $\begin{array}{ll}\text { Сиркові вироби } & 3 \text { напо- } \\
\text { внювачами } & \text { (ДСТУ } \\
\text { 4503:2005) } & \end{array}$ & $\begin{array}{l}\text { Білий } 3 \text { відтінком чи } \\
\text { кольором наповнювача, } \\
\text { рівномірний по всій масі }\end{array}$ & $\begin{array}{l}\text { Чистий, кисломолочний, } \\
\text { iз запахом, смаком і } \\
\text { ароматом наповнювача }\end{array}$ & $\begin{array}{l}\text { Однорідна, ніжна, в міру щіль- } \\
\text { на, з наявністю чи відсутністю } \\
\text { частинок наповнювача }\end{array}$ \\
\hline 2 & $\begin{array}{l}\text { Сирковий десерт нежи- } \\
\text { рний } 3 \text { кріопорошком } \\
\text { "Буряк” }\end{array}$ & $\begin{array}{l}\text { Світло-буряковий, рів- } \\
\text { номірний по всій масі }\end{array}$ & $\begin{array}{l}\text { Чистий, солодкий, злегка } \\
\text { кислуватий, із злегка } \\
\text { вираженим присмаком і } \\
\text { запахом буряка }\end{array}$ & $\begin{array}{l}\text { Однорідна, ніжна, наявні поо- } \\
\text { динокі вкраплення кріопорош- } \\
\text { ку }\end{array}$ \\
\hline 3 & $\begin{array}{l}\text { Сирковий десерт напів- } \\
\text { жирний } 3 \text { кріопорошком } \\
\text { "Буряк” }\end{array}$ & $\begin{array}{l}\text { Малиновий, piвномір- } \\
\text { ний по всій масі }\end{array}$ & $\begin{array}{l}\text { Чистий, солодкий, злегка } \\
\text { кислуватий, з вираженим } \\
\text { присмаком і запахом } \\
\text { буряка }\end{array}$ & $\begin{array}{l}\text { Однорідна, ніжна, наявні вкра- } \\
\text { плення кріопорошку }\end{array}$ \\
\hline
\end{tabular}

Таблиця 4

Основні фізико-хімічні показники сиркових виробів із кріопорошком “Буряк”

\begin{tabular}{|c|c|c|c|c|c|c|}
\hline \multirow{2}{*}{ № ח/п } & \multirow{2}{*}{ Назва сиркової маси } & \multirow{2}{*}{$\begin{array}{c}\text { Кислотність } \\
\left({ }^{\circ} \mathrm{T}\right)\end{array}$} & \multicolumn{3}{|c|}{ Масова частка, \% } & \multirow{2}{*}{$\begin{array}{l}\text { Енергетична цін- } \\
\text { ність (ккал/100 г) }\end{array}$} \\
\hline & & & вологи & $\mathrm{CP}$ & жиру & \\
\hline 1 & $\begin{array}{c}\text { Нормативні величини сирко- } \\
\text { вих виробів }\end{array}$ & $120-180$ & $60-70$ & - & $4-6$ & $120-180$ \\
\hline 2 & $\begin{array}{c}\text { Сирковий десерт нежирний } 3 \\
\text { кріопорошком “Буряк” }\end{array}$ & 136 & 68 & 32 & - & 128 \\
\hline 3 & $\begin{array}{c}\text { Сирковий десерт напівжирний } \\
3 \text { кріопорошком “Буряк” }\end{array}$ & 128 & 63 & 37 & 4,6 & 174 \\
\hline
\end{tabular}

Аналіз цифрового матеріалу даної таблиці свідчить, що додавання кріопорошку певним чином впливає і на фізико-хімічні характеристики. Так, титрована кислотність дослідних зразків солодких сиркових виробів складала $136-128^{\circ} \mathrm{T}$, м.ч. вологи $68-63 \%$ і СР - 32-37\%, а величини енергетичної цінності складали 128 та 174 ккал/100 г продукту.

При розробці нових зразків комбінованих функці-

Таблиця 5

Вміст амінокислот в нежирних солодких сиркових десертах з кріопорошком “Буряк”

\begin{tabular}{|c|c|c|c|c|}
\hline \multirow{3}{*}{ Амінокислоти } & \multicolumn{4}{|c|}{ Зразки сиркових виробів } \\
\hline & \multicolumn{2}{|c|}{ Натуральна } & \multicolumn{2}{|c|}{ з кріопорошком } \\
\hline & г/кг продукту & \% від вмісту амінокислот & г/кг продукту & \% від вмісту амінокислот \\
\hline \multicolumn{5}{|c|}{ Незамінні амінокислоти } \\
\hline Треонін & 7,339 & 4,46 & 7,453 & 4,45 \\
\hline Валін & 9,082 & 5,52 & 9,196 & 5,49 \\
\hline Метіонін & 4,403 & 2,67 & 4,446 & 2,65 \\
\hline Ізолейцин & 9,173 & 5,57 & 9,303 & 5,55 \\
\hline Лейцин & 16,972 & 10,31 & 17,117 & 10,22 \\
\hline Фенілаланін & 8,532 & 5,18 & 8,586 & 5,12 \\
\hline Лізин & 13,302 & 8,08 & 13,501 & 8,06 \\
\hline Триптофан & 1,651 & 1,00 & 1,688 & 1,01 \\
\hline Всього & 70,454 & 42,79 & 71,270 & 42,55 \\
\hline \multicolumn{5}{|c|}{ Замінні амінокислоти } \\
\hline Аспарагінова кислота & 9,174 & 5,57 & 9,883 & 5,90 \\
\hline Серин & 7,523 & 4,57 & 7,659 & 4,57 \\
\hline Глютамінова кислота & 30,274 & 18,38 & 30,866 & 18,43 \\
\hline Пролін & 18,348 & 11,14 & 18,450 & 11,01 \\
\hline Гліцин & 2,385 & 1,45 & 2,467 & 1,47 \\
\hline Аланін & 4,036 & 2,45 & 4,122 & 2,46 \\
\hline Цистин & 1,376 & 0,84 & 1,408 & 0,84 \\
\hline Тирозин & 8,532 & 5,18 & 8,640 & 5,16 \\
\hline Гістидин & 5,137 & 3,12 & 5,167 & 3,08 \\
\hline Аргінін & 7,431 & 4,51 & 7,589 & 4,53 \\
\hline Всього & 94,210 & 57,21 & 96,251 & 57,45 \\
\hline Разом & 164,664 & 100 & 167,521 & 100 \\
\hline
\end{tabular}

ональних продуктів важливо визначати їх харчову та біологічну цінність.

3 цією метою було проведено дослідження амінокислотного складу білка традиційних та дослідних зразків нежирних і напівжирних солодких сиркових виробів з добавкою кріопорошка “Буряк” (табл. 5, 6). 
Таблиця 6

Вміст амінокислот в солодких напівжирних сиркових десертах з кріопорошком “Буряк”

\begin{tabular}{|c|c|c|c|c|}
\hline \multirow{3}{*}{ Амінокислоти } & \multicolumn{4}{|c|}{ Зразки сиркових виробів } \\
\hline & \multicolumn{2}{|c|}{ Натуральна } & \multicolumn{2}{|c|}{ з кріопорошком } \\
\hline & г/кг продукту & \% від вмісту амінокислот & г/кг продукту & \% від вмісту амінокислот \\
\hline \multicolumn{5}{|c|}{ Незамінні амінокислоти } \\
\hline Треонін & 6,859 & 4,58 & 7,031 & 4,56 \\
\hline Валін & 8,713 & 5,82 & 8,885 & 5,77 \\
\hline Метіонін & 4,185 & 2,79 & 4,250 & 2,76 \\
\hline Ізолейцин & 7,516 & 5,02 & 7,711 & 5,00 \\
\hline Лейцин & 13,960 & 9,32 & 14,177 & 9,20 \\
\hline Фенілаланін & 8,299 & 5,54 & 8,445 & 5,48 \\
\hline Лізин & 10,981 & 7,33 & 11,279 & 7,32 \\
\hline Триптофан & 1,782 & 1,19 & 1,824 & 1,22 \\
\hline Всього & 62,295 & 41,59 & 63,602 & 41,31 \\
\hline \multicolumn{5}{|c|}{ Замінні амінокислоти } \\
\hline Аспарагінова кислота & 8,830 & 5,90 & 9,894 & 6,42 \\
\hline Серин & 7,201 & 4,81 & 7,353 & 4,77 \\
\hline Глютамінова кислота & 27,804 & 18,57 & 28,693 & 18,60 \\
\hline Пролін & 16,445 & 10,98 & 16,597 & 10,77 \\
\hline Гліцин & 2,340 & 1,56 & 2,463 & 1,60 \\
\hline Аланін & 3,933 & 2,63 & 4,063 & 2,64 \\
\hline Цистин & 1,116 & 0,74 & 1,165 & 0,76 \\
\hline Тирозин & 8,245 & 5,50 & 8,407 & 5,46 \\
\hline Гістидин & 4,779 & 3,19 & 4,824 & 3,13 \\
\hline Аргінін & 6,769 & 4,52 & 7,006 & 4,54 \\
\hline Всього & 87,462 & 58,41 & 90,465 & 58,69 \\
\hline Разом & 149,757 & 100 & 154,068 & 100 \\
\hline
\end{tabular}

Як показали результати досліджень додавання до нежирної солодкої сиркової маси кріопорошку з буряка в кількості 18,3 г на 1 кг продукту обумовило збільшення загальної кількості амінокислот на 1,73\%, а в їх складі незамінних амінокислот на $1,16 \%$ та замінних - на 2,17\%.

Збільшення суми незамінних амінокислот відбувалося більшою мірою завдяки зростанню концентрації треоніну на $1,55 \%$, валіну на $1,25 \%$, ізолейцину на $1,72 \%$, лізину на $1,50 \%$, зростання решти незамінних амінокислот було в межах 0,60-0,85\%.

Більш помітні зміни встановлено в складі замінних амінокислот, серед яких помітно більше зростання аспарагінової кислоти $(7,73 \%)$, майже в 2 рази менше гліцину $(3,44 \%)$. Однаковим та дещо менше було збільшення концентрації серину $(1,81 \%)$, глютамінової кислоти $(1,95 \%)$, аланіну $(2,14 \%)$, цистину $(2,35 \%)$, аргініну $(2,12 \%)$. Незначно зростав уміст проліну $(0,55 \%)$, тирозину $(1,26 \%)$ та гістидину $(0,59 \%)$.

Добавка до напівжирної солодкої сиркової маси 27,03 г на 1 кг маси комбінованого виробу кріопорошку "Буряк" обумовлювала порівняно зі зразком, виготовленим із нежирною солодкою сирковою масою, більш значне зростання як загальної кількості амінокислот $(2,66 \%)$, так суми незамінних $(2,10 \%)$ та замінних $(3,43 \%)$ амінокислот.

Сума незамінних амінокислот більшою мірою зростала завдяки лізину $(2,72 \%)$, ізолейцину (2,59\%), треоніну (2,51\%) та триптофану (2,37\%). Дещо менше зростала концентрація валіну $(1,97 \%)$, фенілаланіну $(1,76 \%)$, лейцину $(1,56 \%)$ та метіоніну $(1,55 \%)$.

Із замінних амінокислот, як і в комбінованому зразку нежирної солодкої сиркової маси найбільшим було збільшення вмісту аспарагінової кислоти $(12,05 \%)$ та гліцину $(5,27 \%)$. Також помітно більше було зростання вмісту цистину $(4,39 \%)$, аргініну $(3,50 \%)$, аланіну $(3,30 \%)$, глютамінової кислоти $(3,20 \%)$. Незначно збільшувалась концентрація проліну $(0,93 \%)$, тирозину $(1,97 \%)$ та гістидину $(0,95 \%)$.

Збільшення вмісту амінокислот в нежирних і напівжирних солодких сиркових масах з додаванням кріопорошку “Буряк” було обумовлено більшим вмістом в рослинній сировині $(18,54 \%)$, ніж сиркових масах (16,51 i 15,02\%). Помітніше зростання цілого ряду замінних амінокислот в комбінованих зразках сиркових мас пояснюється тим, що в рослинних білках порівняно $з$ тваринними міститься більше цих амінокислот. Так, в білку кріопорошку з буряка незамінні амінокислоти складали 30,48\%, замінні - 69,52\%, а в нежирній i напівжирній солодких сиркових масах відповідно 42,79 і 41,59\% та 57,91 і 58,41\%.

Важливо відзначити, що в комбінованих зразках сиру з кріопорошком "Буряк” в розрахунку на 100 г білка зберігалося таке ж співвідношення між сумами незамінних і замінних амінокислот як і в традиційних зразках. В натуральному та комбінованому зразку нежирних солодких сиркових мас частка незамінних амінокислот складала 42,79 і 42,53\%, замінних - 57,21 i 57,45\%, а в напівжирних зразках відповідно 41,59 і $41,31 \%$ та 58,41 і 58,69\%. Збереження такого співвідношення є важливим з огляду на те, що в комбінованих зразках зберігається рівень засвоєння та використання амінокислот в організмі людини не нижчий, ніж в натуральному продукті. Виходячи з того, що одночасне споживання тваринних білків зумовлює зростання перетравності рослинних білків та засвоєння, можна сподіватися, що комбіновані зразки сиркових 
мас повинні мати підвищену харчову цінність білкового компоненту.

Особливості виробництва сиркових виробів визначають специфіку його мікрофлори. У процесі виробництва цієї групи продукції у ній створюються сприятливі умови для розвитку сторонньої мікрофлори, особливо психотропних протеолітичних і ліполітичних мікроорганізмів. Тому строгий мікробіологічний контроль тут вкрай потрібний.

Узвязку із цим в умовах виробничої лабораторії були проведені мікробіологічні дослідження дослідних зразків солодких сиркових мас із кріопорошком “Буряк”. Згідно з вимогами мікробіологічного контролю були досліджені кількість життєздатних клітин молочнокислих мікроорганізмів та наявність бактерій групи кишкової палички. Також визначено величину титрованої кислотності під час нормативного часу зберігання дослідних зразків із кріопорошком “Буряк”.

В процесі нормативного часу зберігання зразки готової продукції зберігали нормативні величини титрованої кількості. Слід відзначити, що приріст титрованої кислотності у зразках напівжирних був дещо меншим.

Аналіз динаміки змін титрованої кількості та кількості життєздатних клітин молочнокислих мікроорганізмів показує, що у дослідних зразках нежирних сиркових мас у процесі їх зберігання виявлено менш стабільніші величини, ніж у зразках напівжирних. Слід особливо зазначити, що у нежирних величини приросту титрованої кислотності були більш стрімкими, а це обмежує нормативне зберігання та використання. У жодному з дослідних зразків в процесі зберігання наявність БГКП (у різних розведеннях) підтверджена не була.

Таким чином, обгрунтовано доцільність використання кріопорошку “Буряк” в технології сиркових виробів різної жирності, що підвищує їх біологічну цінність. Також необхідно підкреслити доцільність використання кріопорошків, які мають високий міст вітамінів, мінеральних речовин, харчових волокон в харчовій промисловості.

\section{Висновки}

1. Обгрунтовано доцільність використання кріопорошку “Буряк” у технології нових солодких сиркових виробів. Запропоновано оптимальну дозу кріопорошку “Буряк” для сиркових десертів нежирних та напівжирних у кількості відповідно 18,3 та 27,3 кг на 1000 кг готового продукту.

2. При дослідженні органолептичних показників сиркових виробів із використанням кріопорошку “Буряк” встановлено, що вони суттєвих змін не зазнали. Смак дослідних зразків був солодким 3 присмаком кріопорошку, більш вираженим у солодких напівжирних зразках Консистенція дослідних зразків була однорідною та ніжною. Солодкі сиркові вироби за умов застосування кріопорошку "Буряк” мали фізикохімічні та мікробіологічні характеристики в межах норми.

3. Виявлені зміни в амінокислотному складі сир- кових десертів вказують на те, що використання кріопорошку “Буряк” дозволяє підвищити харчову та біологічну цінність білкової складової. Зокрема встановлено збільшення загальної кількості амінокислот на $1,73 \%$, а в складі незамінних амінокислот на 1,16\% та замінних - на 2,17 \%. Розроблені сиркові вироби рекомендовано включати до раціону населення як джерело біологічно активних речовин.

4. Зміни мікрофлори сиркових виробів із кріопорошком протягом нормативного терміну зберігання заходилась в межах норми.

\section{References}

Bazhai-Zhezherun, S. A. (2016). Morozyvo z ekstraktom stevii herodiietychnoho pryznachennia. Problemy starenija i dolgoletija, 25(2), 287-297 (in Ukrainian).

Bilyk, O., Slyvka, N., Gutyj, B., Dronyk, H., \& Sukhorska, O. (2017). Substantiation of the method of protein extraction from sheep and cow whey for producing the cheese "Urda". Eastern-European Journal of Enterprise Technologies, 3 (11(87)), 18-22. doi: 10.15587/1729-4061.2017.103548.

Boichak, Ya. Koberniuk, V., \& Petryk, L. (2018). Novi vydy i formy biodobavok $\mathrm{v}$ tekhnolohii molochnykh produktiv LPN. Dni studentskoi nauky u LNUVM ta BT imeni S.Z Hzhytskoho: Materialy studentskoi konferentsii. Lviv, 79-80 (in Ukrainian).

Borys, O.M., \& Tsisaryk, O.Y. (2016). Tekhnolohiia kyslomolochnoho napoiu z synbiotychnymy vlastyvostiamy. Materialy Mizhnarodnoi konferentsiia "Dni studentskoi nauky" u Lvivskomu natsionalnomu universyteti veterynarnoi medytsyny ta biotekhnolohii imeni S.Z. Hzhytskoho. Lviv, 92-93 (in Ukrainian).

Gutyj, B., Hachak, Y., Vavrysevych, J., \& Nagovska, V. (2017). The influence of cryopowder "Garbuz" on the technology of curds of different fat content. EasternEuropean Journal of Enterprise Technologies, 2(10(86)), 20-24. doi: 10.15587/17294061.2017.98194.

Hachak, Y., Gutyj, B., Bilyk, O., Nagovska, V., \& Mykhaylytska, O. (2018). Effect of the cryopowder "Amaranth" on the technology of meolten cheese. Eastern-European Journal of Enterprise Technologies, 1 (11(91)), 10-15. doi: 10.15587/17294061.2018.120879.

Hachak, Yu.R. (2011). Molochni produkty likuvalnoprofilaktychnoho pryznachennia. Posibnyk. Lviv (in Ukrainian).

Hoiko, I.Yu. (2016). Rozroblennia fitokompozytsii dlia vyrobnytstva funktsionalnykh kyslomolochnykh syriv. Problemy starenija i dolgoletija, 25(2), 273-279. http://nbuv.gov.ua/UJRN/PSD_2016_25_2_12 (in Ukrainian).

Horyuk, Yu.V., Kukhtyn, M.D., Perkiy, Yu.B., Horyuk, V.V., \& Semenyuk, V.I. (2016). Identification of Enterococcus isolated from raw milk and cottage cheese "home" production and study of their sensitivity to antibiotics. Scientific Messenger LNUVMBT named after S.Z. Gzhytskyj, 18, 3(70), 44-48. doi: 10.15421/nvlvet7011.

Hrek, O.V., \& Skorchenko, T.A. (2012). Tekhnolohiia 
kombinovanykh produktiv na molochnii osnovi: Pidruchnyk. K.: NUKhT (in Ukrainian).

Ilinska, A., Benytska, A., \& Prystanskyi, R. (2017). Krioporoshky $\mathrm{v}$ yakosti biodobavok u molochnykh produktakh LPN. Aktualni zadachi suchasnykh tekhnolohii 6 zbirnyk tez dopovidei n. t. konferentsii molodykh uchenykh ta studentiv. Ternopil, 174-175 (in Ukrainian).

Koberniuk, V., Ilinska, A., \& Hrabarchuk, O. (2018). Novi vydy krioporoshkiv $\mathrm{v}$ tekhnolohii molochnykh produktiv LPN. Dni studentskoi nauky u LNUVM ta BT imeni S.Z Hzhytskoho: Materialy studentskoi konferentsii. Lviv, 103-104 (in Ukrainian).

Lisovska, Yu., \& Puneiko, O. (2018). Rozrobka retseptur molochnykh produktiv LPN iz krioporoshkom iz moreproduktiv. Dni studentskoi nauky u LNUVM ta BT imeni S.Z Hzhytskoho: Materialy studentskoi konferentsii. Lviv, 110-111 (in Ukrainian).

Mazaraky, A.A., Peresichnyi, M.I., \& Kravchenko, M.F. (2012). Tekhnolohiia produktiv funktsionalnoho pryznachennia. K., Kyiv. nats. torh.-ekon. Universtet (in Ukrainian).

Nagovska, V., Hachak, Y., Gutyj, B., Bilyk, O., Slyvka, N. (2018). Influence of wheat bran on quality indicators of a sour milk beverage. Eastern-European Journal of Enterprise Technologies, 4 (11(94)), 28-34. doi: 10.15587/1729-4061.2018.140093

Nagovska, V.O., Hachak, Yu.R., Bilyk, O.Ya., Gutyj, B.V., Slyvka, N.B., \& Mikhailytska, O.R. (2018). Influence of thistle grist on organoleptic, physicochemical and microbiological parameters of kefir. Scientific Messenger of Lviv National University of Veterinary Medicine and Biotechnologies, 20(85), 166-170. doi: 10.15421/nvlvet8530.

Nahovska, V., Hachak, Y., Myhaylytska, O., \& Slyvka, N. (2017). Application of wheat brans as a functional ingredient in the technology of kefir. Scientific Messenger LNUVMB, 19(80), 52-56. doi: 10.15421/nvlvet8011.

Pavliuk, R.Yu., Poharska, V.V., Khomenko, A.V., \& Kostrova, K.V. (2013). Biotekhnolohiia kyslomolochnykh napoiv z vykorystanniam skolotyny ta dobavok iz prianykh ovochiv. Vostochnoevropejskij zhurnal peredovyh tehnologij, 4 (10(64)), 53-57. http://nbuv.gov.ua/UJRN/Vejpte_2013_4$10 \_14$ (in Ukrainian).

Pukivskyi, P., Turchyn, I., Slyvka, N., \& Mykhailytska, O. (2015). Vykorystannia roslynnoi syrovyny $\mathrm{v}$ tekhnolohii syrkovykh mas. Naukovyi visnyk Lvivskoho natsionalnoho universytetu veterynarnoi medytsyny ta biotekhnolohii imeni S.Z. Gzhytskoho, 17(4), 105-109 (in Ukrainian).

Samilyk, M. (2017). Improving the technology of soft sour milk cheese by increasing biological value. Scientific Messenger of Lviv National University of Veterinary Medicine and Biotechnologies, 19(80), 3337. doi: 10.15421/nvlvet8007.

Simakhina, H. O. (2011). Biolohichna tsinnist ta funktsionalna diia komponentiv krioporoshkiv tsukrovykh buriakiv. Tsukor Ukrainy, 6-7. http://dspace.nuft.edu.ua/jspui/handle/123456789/328 (in Ukrainian).

Syrokhman, I.V., \& Zahorodnia, V.M. (2009). Tovaroznavstvo produktiv funktsionalnoho pryznachennia. Navchyi posibnyk dlia studentiv VNZ. Kyiv (in Ukrainian).

Turchyn, I., Zalensky, M., \& Voychishin, A. (2018). Development of technology of cereal past with combined composition. Scientific Messenger of Lviv National University of Veterinary Medicine and Biotechnologies, 20(85), 24-28. doi: 10.15421/nvlvet8505. 